\title{
Characteristics of auditors' non-audit services and accruals quality in Malaysia
}

\author{
Wahab Effiezal Aswadi Abdul \\ School of Accounting, Curtin University, Bentley, Australia \\ Wan Zurina Nik Abdul Majid \\ Faculty of Accountancy, Universiti Teknologi MARA, Shah Alam, Malaysia \\ Iman Harymawan \\ Department of Accounting, Universitas Airlangga, Surabaya, Indonesia, and \\ Dian Agustia \\ Faculty of Economics and Business, Universitas Airlangga, Surabaya, Indonesia
}

Accruals

quality in

Malaysia

Received 5 October 2018 Revised 22 December 2019 Accepted 29 December 2019

\begin{abstract}
Purpose - The purchase of non-audit services from incumbent auditors has generated considerable attention. This study aims to examine the relationship between characteristics of non-audit services, namely, the recurrence and types of services, and accruals quality in Malaysia.

Design/methodology/approach - This study analyzed hand-collected audit and non-audit fees of 1,117 observations from Malaysian firms from 2009 to 2011. This study used descriptive analysis, univariate tests and multivariate regression to investigate the potential effect of non-audit services on accruals quality.

Findings - Non-audit services are associated with lower accruals quality. Recurring and non-recurring nonaudit service fees are detrimental to the quality of accruals, as are all types of recurring non-audit services. Only non-recurring audit-related services decrease accruals quality. The results demonstrate that provisions of non-audit services create economic bonding, and thus a threat to auditor independence. Results remain robust with the inclusion of corporate governance and institutional variables.

Research limitations/implications - The sample period might represent a limitation as it only covers three years of data. This limitation is mainly because of the nature of data collection of the non-audit services fees. Practical implications - The findings could suggest a refinement on the Malaysian Institute of Accountants (MIA) by-laws focusing on auditor independence, and it could assist other regulative bodies such as the Securities Commission, the stock exchange (Bursa Malaysia) in ensuring better governance on the provision of non-audit services.
\end{abstract}

Originality/value - This study is the first that provides evidence on the relationship between non-audit services, types, and recurring and non-recurring non-audit services and accruals quality in Malaysia.

Keywords Auditor independence, Accruals quality, Non-audit services, Knowledge spillover, Economic bonding, Audit quality

Paper type Research paper

\section{Research aims}

Evidence examining the impact of non-audit services on auditor independence is rather extensive. Beginning with the seminal work of Simunic (1984) on non-audit services to

JEL classification - M42

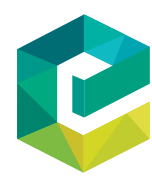

Pacific Accounting Review Vol. 32 No. 2, 2020 pp. $147-175$ hing Limited 0114-0582 
PAR

32,2

reviews by Francis et al. (2004, 2006), Schneider (2006) reflects the importance of examining this issue even further. In Malaysia, Che Ahmad et al. (2006) and Abdul Wahab et al. (2013) examine the relationship between non-audit services and audit fees and audit opinion. Abdul Wahab and Mat Zain (2013) examine auditor independence by investigating the activity of lowballing after the initial engagement. Although they find fees discount exists during the initial engagement, no evidence suggests that impairment of independence exists as auditors will earn a premium in fees after subsequent years. These studies, however, do not take into consideration other factors that are deemed necessary in analyzing the impact of non-audit services on auditor independence. Globally, limited evidence has been presented in establishing the impact of various characteristics of non-audit services. As highlighted by Alexander and Hay (2013), the limitation is mainly because of data unavailability.

We offer four central objectives in this paper. The first is to investigate the relationship between auditors' non-audit services and accruals quality in Malaysia. The premise of such a link is simple, but the effect of non-audit services is somewhat ambiguous. The provision of non-audit services will result in economic bonding, or knowledge spillover could mean a decrease or an increase in accruals quality, respectively.

The second objective is to investigate the impact of types of non-audit services on accruals quality. Several studies (Abdul Wahab et al., 2014; Alexander and Hay, 2013; Huang et al., 2007; Paterson and Valencia, 2011; Walker and Hay, 2013) have suggested that certain types of non-audit services have different effects as related to economic bonding or knowledge spillover on audit services. We segregated the non-audit services as tax-related, audit-related and other non-audit services. The third objective is to investigate the nature of these services, whether it is recurring or non-recurring, and its impact on accrual quality. Schneider et al.'s (2006) review of non-audit services raises the importance of addressing the subject of recurring and non-recurring non-audit services because ignoring them "muddies the waters" makes it challenging to interpret empirical results. Competing views exist on the impact of recurring non-audit services. Beck et al. (1988a) and Schneider et al. (2006) argue that recurring non-audit services provide knowledge spillover. Causholli et al. (2014) suggest that future non-audit services create economic bonding and thus undermine auditor independence. By contrast, Beck et al. (1988a) indicate that non-recurring could undermine auditor independence, whereas Causholli et al. (2014) suggest otherwise. The final objective is to test the types and recurrence of these services simultaneously.

Malaysia is chosen for several reasons. First, there is limited evidence on the role of nonaudit services in the region. Several papers have examined the role of non-audit services in Malaysia. Che Ahmad et al. (2006) and Abdul Wahab et al. (2013, 2014, 2015) examine the relationship between non-audit and audit fees, the propensity of the going-concern audit opinion and financial restatements. The findings are mixed and inconclusive, as some studies identify the support of knowledge spillover (Che Ahmad et al., 2006; Abdul Wahab et al., 2014), whereas others (Abdul Wahab et al., 2013, 2015) identify no such support. However, none of the abovementioned studies examines the impact of non-audit services on accruals quality. Second, Malaysia requires the disclosure of the non-audit services as part of the listing requirements, and the annual reports provide information on the nature of these services. Third, evidence regarding the nature and recurrence of non-audit services is limited.

We are motivated for several reasons. First, as described by Habib (2012), the evidence regarding the relationship between non-audit services and earnings quality is ambiguous. Second, the study on earnings quality in Malaysia has been limited to an investigation of the role of the International Financial Reporting Standards (IFRS) and earnings quality by 
Wan Ismail et al. (2013), corporate governance (Abdul Rahman and Mohamed Ali, 2006; Mohd Saleh et al., 2007; Hasnan et al., 2013), internal audit function (Johl et al., 2013) and audit opinion (Johl et al., 2007). However, no studies on earnings quality exist that include an investigation of the impact of non-audit services in Malaysia, which suggests that this study is timely. A recent study by Lai et al. (2016) investigates the relationship between busy auditors, ethical behavior and discretionary accruals in Malaysia but does not include nonaudit services in their tests.

Similar to Srinidhi and Gul (2007) and Causholli et al. (2014), we choose accruals as our proxy of audit quality or loss of independence. We extend the work of Abdul Wahab et al. (2014) because that study focuses on financial restatements, whereas our study measures the impact on accruals quality. The choice of accruals quality as our dependent variable as opposed to a binary measure (Abdul Wahab et al., 2014) as this measure provides a variation of earnings quality across the sample. Also, the residual values of the accruals model have been known to capture managerial discretion and estimation errors (Dechow et al., 2010). We measure accruals quality using a modification of the Dechow and Dichev (2002) measure, as suggested by Francis et al. (2005).

Based on 1,117 firm-year observations from 2009 to 2011, and using the accruals model of Francis et al. (2005), we find that non-audit services affect accruals quality negatively and significantly by increasing the estimation error, which suggests that non-audit services create economic bonding, which could affect auditor independence. Our results are similar to those of Srinidhi and Gul (2007), who find that fees paid to auditors affect accruals quality. We find that all types of non-audit services affect accruals quality negatively and significantly. Our results are interesting, as we find that both recurring and non-recurring non-audit fees affect accruals quality negatively and significantly.

This augments the existing literature to papers such as Alexander and Hay (2013), Paterson and Valencia (2011), and Abdul Wahab et al. (2014). We find that all types of nonaudit service of a recurring nature work negatively against accruals quality. In addition, we find that non-recurring audit-related non-audit services decrease accruals quality. The result shows that the provision of non-audit services done by the incumbent auditors affects the accruals quality, a signal of independent auditor issue. The same results hold for types of non-audit services for the recurring. The findings could suggest a refinement on the Malaysian Institute of Accountants (MIA) by-laws focussing on auditor independence, and it could assist other regulative bodies such as the Securities Commission, the stock exchange (Bursa Malaysia), in ensuring better governance on the provision of non-audit services.

We discuss the audit market in Malaysia in Section 2. We outline the rationale behind our hypotheses and describe our sample in Sections 3 and 4, respectively. Sections 5 and 6 present the research methodology and results, respectively. Section 7 provides the concluding the remarks.

\section{Institutional background}

\subsection{Audit market in Malaysia}

The accounting profession is not the only group responsible for instituting proper accounting and auditing systems. The profession is supported by regulatory bodies such as the Securities Commission, the Central Bank and the Company Commission of Malaysia; the Accountant's General Office and the Auditor's General Office or Department; and corporate players and directors and managers of companies. These bodies have a significant role in ensuring that a sound financial-reporting system is in place to protect public interests.

To strengthen the independence of external auditors, the MIA has established by-laws on professional ethics, conduct and practice. Section 290 indicates that under the 
PAR

32,2

Independence-Assurance Engagements, members of the assurance team and the firm should be independent of the client during the period of engagement. The rules also require that all companies that are listed on the Bursa Malaysia Listing Requirement disclose the amount of non-audit services that are provided by an external auditor. The revised Malaysian Code on Corporate Governance (2012) suggests that the audit committee should establish policies that govern the circumstances under which contracts for the provision of non-audit services can be entered into and procedures that must be followed by the external auditors[1]. However, this code does not provide information on whether a formal approval is required from an audit committee to purchase non-audit services.

The amount of the fees paid for non-audit services is not regulated or restricted under any legislation or act. However, the amount incurred should be included or disclosed in annual reports under items (18) and (19) of acdix 9C of the Bursa Malaysia Listing Requirements for main markets and the Access, Certainty, Efficiency market, respectively. Therefore, publically listed companies are required to disclose non-audit fees that are paid to corporations that are owned by external auditors or their partners. This disclosure clause was made mandatory by Bursa Malaysia in 2001 and aimed to protect shareholders' interests and increase corporate transparency. Before 2001, regulators in Malaysia emphasized only the disclosure of audit fees in companies' annual reports, as required by the Companies Act 1965 . However, the rules did not clarify whether clients need to specify the type or nature of non-audit services engagement.

The Malaysian audit market differs from that of other developed countries in that it is not competitive, because corporate governance is based on politically connected companies, ethnicity, language and religion (Abdul Wahab et al., 2011; Haniffa and Cooke, 2002; Yatim et al., 2006). A significant impact on auditing practices occurred in 2002 when the accounting company Arthur Andersen ceased to practice in Malaysia in the fallout from the Enron case, and this challenged auditor independence because of the auditors' financial reliance on the provision of non-audit services. Most firms that, until then, had been audited by Arthur Andersen, switched to Ernst and Young, who, along with Price Waterhouse Coopers, KPMG and Deloitte, dominate the Malaysian audit market.

\section{Research hypotheses}

\subsection{Auditors' non-audit services and accruals quality}

Contrasting views exist in the role of non-audit services (Francis et al., 2004; Habib, 2012; Schneider et al., 2006). First is the view that non-audit services provided by auditors lead to knowledge spillover and thus increase the audit quality. This view proposes a positive link between non-audit services and accruals quality. Kinney et al. (2004) offer three bases for a positive relationship between non-audit services and the quality of financial reporting. First is knowledge spillover; because non-audit services improve audit effectiveness, they assist the auditor in developing a better understanding of the client's business (Simunic, 1984). For instance, knowledge of a client's computer system or tax accounting could be used in the audit, improve the audit and therefore increase the financial-reporting quality (Kinney et al., 2004). Second, the analytical model of Dopuch et al. (2003) suggests that high-quality clients with low misstatement risks are low ex-ante and that non-audit services to such clients provided by their audit firms may increase their reputation capital. This, in turn, increases the incentive for thoroughness in the audit and independence in reporting decisions. Benston (1975) and Antle (1984) argue that on the general basis of contractual service, the desire for non-audit services to improve their reputation encourages them to remain strongly independent. 
The provision of non-audit services allows auditors to invest more in such reputational capital, and they are unlikely to jeopardize their reputation to accommodate a client (Arruñada, 1999; Dopuch et al., 2003). Third, high-quality clients may seek more expert computer systems and tax advice, internal audit services, and other audit-related transaction services, and they may prefer that a particular audit firm supply these non-audit services because of their quality or price. Based on these arguments, we would expect a positive relationship between non-audit services and earnings quality.

An opposing view is that the provision of non-audit services may lead to economic bonding between the auditor and the auditee, with the possibility of weakening the audit quality and thus affecting the accruals quality. This economic dependence or bond argument (Kinney et al., 2004; Francis, 2006) suggests that a negative relationship exists between non-audit services and financial reporting quality. As such economic dependence increases over time, the auditor may grow less willing to challenge possible misstatements in the client's financial statements. Agrawal and Chadha (2005) suggest that the provision of non-audit services could hurt the quality of an audit by impairing auditor independence as a direct consequence of the increase in economic bond and dependence. Koh et al. (2013) argue that the provision of non-audit services by an incumbent auditor provides the client with leverage because withholding non-audit services business penalizes the auditor without affecting the client. Auditors placed in this position are more likely to accommodate client preferences in return for being awarded non-audit services, which undermines the auditors' independence (Koh et al., 2013), and leads to a lower earnings quality[2]. Srinidhi and Gul (2007) argue that the relative differences in the regulative environment between audit and non-audit services allow for the inclusion of rent in non-audit services, which makes it easier for managers to influence auditors by including excessive rents in the non-audit fees instead of in the audit fees.

Studies have produced mixed results. Those that find a positive relationship between the provision of non-audit services fees and accruals quality, which denotes knowledge spillover, are those of Koh et al. (2013), Larcker and Richardson (2004), and Antle et al. (2006). By contrast, Dee et al. (2006), Mande and Son (2015), Reynolds et al. (2004), Lim et al. (2013), Frankel et al. (2002) and Srinidhi and Gul (2007) find a negative relationship between nonaudit service fees and accruals quality, which indicates that these services denote economic bonding that undermines auditor independence. Another group of studies (Lim and Tan, 2008; Mitra, 2007; Chung and Kallapur, 2003; Ashbaugh et al., 2003) finds weak or no evidence of a relationship between non-audit services and earnings quality. Based on the above arguments, we expect an association between non-audit fees and accruals quality.

\subsection{Heterogeneity of non-audit services}

3.2.1 Types of non-audit services. The heterogeneous nature of non-audit services is pivotal in understanding their role. Different types of non-audit services have different characteristics that affect whether they result in knowledge spillover or deepen the economic bonding of the auditors. Our choice of types of non-audit service is accepted widely in the literature as that usually offered by auditors to their auditees.

Most studies examine types of non-audit service centers on tax services. Krishnan et al. (2013) outline three benefits associated with auditor-provided tax services. First, the overall cost of these services will be less. Next, knowledge spillover, which is the insight that is gained in providing tax services, can enhance audit effectiveness, and, in turn, the quality of the client's financial reporting. The knowledge spillover that is communicated between tax and audit partners may mitigate auditor information asymmetry. Alternatively, providing such services could increase an auditor's economic dependence on a client, Krishnan et al. (2013) find that 
PAR

32,2

auditor-provided tax services enhance the value relevance of earnings; this supports their argument on knowledge spillover.

Seetharaman et al. (2011) examine the relationship between tax-related non-audit services and tax-related financial restatements and find a negative relationship. They argue that taxrelated non-audit services provide knowledge spillover to the incumbent auditor and thus reduce the probability of tax-related financial restatements. However, they find no relationship between tax-related non-audit services and overall financial restatements. Robinson (2008) investigates the relationship between auditor-provided tax services and going-concern opinions and finds a positive relationship. Findings from tax-related studies suggest that tax-related audit services provide knowledge spillover and enhance financial reporting quality. Paterson and Valencia (2011) find that recurring auditor-provided tax services have a significant negative association with restatements, which is consistent with the notion that tax services generate knowledge spillover, which improves audit quality. Abdul Wahab et al. (2014) find a negative and significant relationship between tax-related non-audit services and the likelihood of financial restatements. Based on these arguments, we predict that the discretionary accruals are likely to be lower for firms that purchased taxrelated non-audit services.

The next type of non-audit service is audit-related. Following the argument of Beck et al. (1988b), which benefits or detracts from the provision of non-audit services depending on relative start-up costs, switching costs and knowledge spillover, audit-related non-audit services should be closely related to audits and thus should provide knowledge spillover. Similarly, we predict that the accruals quality is likely to be lower for firms that purchased audit-related non-audit services.

Our third type is other non-audit services, those that are neither tax-related nor auditrelated non-audit services[3]. Examples of other non-audit services are a review of an internal control system and a revision of the IFRS conversion. Lai and Krishnan (2009) investigate the relationship between financial information system-related services, which includes the design of internal accounting systems, as provided by the incumbent auditor and firm value. Lai and Krishnan (2009) argue that such a provision could provide knowledge spillover and could impair auditor independence. They claim that an auditorprovided financial information system is more likely to meet audit needs as they already know how the system works, which increases operational efficiency. They also argue that it is possible that the auditor may not report financial restatements based on the system that they designed. Based on this argument, we predict an association between other non-audit services and accruals quality.

Based on Malaysian data, Abdul Wahab et al. (2014) find that audit-related non-audit services reduce the likelihood of financial restatements, but other related non-audit services do not.

3.2.2 Recurring vs. non-recurring non-audit services. The method developed by Beck et al. (1988a) differentiates between the benefits gained from recurring and non-recurring, or one-off, non-audit services to clients. Beck et al. (1988a) suggest that recurring non-audit service engagements are more likely to generate knowledge spillover or differential benefits that increase auditor independence. Ezzamel et al. (2002) state that the existence of cost benefits from the joint provision of non-audit and audit services must be considered in terms of recurring and non-recurring services. Recurring non-audit services generate a stream of quasi-rents or annuity, which influences the economic bond between auditor and client (Alexander and Hay, 2013).

A similar argument was mooted by Causholli et al. (2014), which predicts that future nonaudit services business could impair auditor independence. They argue that future 
non-audit services fees present an important source of career advancement and, with it, a source of a particularly strengthened economic bond with the client. Causholli et al. (2014) argue that an economic bond could intensify in the presence of financial incentives that promote revenue growth, because it encourages audit partners to pursue revenue-generating opportunities. Based on Beck et al.'s (1988a) and Causholli et al.'s (2014) arguments, a negative relationship will exist between recurring non-audit services fees and accruals quality (positive coefficients).

Evidence that examines the impact of non-recurring non-audit fees has been mixed. A subsequent paper by Beck et al. (1988b) finds that recurring non-audit fees are somewhat associated with a higher auditor tenure and increase bonding, which impairs auditor independence. Paterson and Valencia (2011) find that recurring tax-related non-audit services are associated negatively with financial restatements. Similarly, Abdul Wahab et al. (2014) find that tax-related and audit-related non-audit fees are associated negatively with financial restatements. Causholli et al. (2014) investigate the impact of future non-audit fees and discretionary accruals and their proxy for earnings management and find a positive relationship, which suggests that future non-audit services impairs auditor independence.

The situation is somewhat different when non-audit services are performed intermittently, that is, for non-recurring services. Knowledge spillover from the joint provision of services provides the incumbent auditor with a potentially long-term cost advantage or monopoly that competitors will be unable to match with their standard audit costs. Therefore, the incumbent auditor will charge the client a higher fee for the engagement. The auditor is aware that competitors may be able to win the engagement in any future period. However, the savings derived from knowledge spillover mean that competitors' typical audit costs will be higher than those of the incumbent auditor, and so higher profits can be earned (Alexander and Hay, 2013). Based on the arguments by Causholli et al. (2014), one would expect that non-recurring non-audit services do not impair auditor independence as this arrangement does not generate future revenue-generating opportunities and thus could have less impact on auditor independence.

DeBerg and Kaplan (1991) use the types of non-audit service as a proxy for whether fees are recurring or non-recurring. They find that, regardless of whether services are recurring or not, firms are less likely to change auditors. Parkash and Venable (1993) examine the determinants of recurring and non-recurring non-audit services fees and argue that knowledge spillover and economic bonding are higher when recurring non-audit services are provided. Because the relationship is ambiguous, we predict an association between the level of accruals with recurring and non-recurring non-audit fees.

3.2.3 Types of recurring and non-recurring non-audit service. As do Paterson and Valencia (2011) and Abdul Wahab et al. (2014), we extend our test by incorporating both characteristics, namely, types, and whether services are recurring or not. A theoretical argument that is raised by Krishnan et al. (2013) and Paterson and Valencia (2011) suggests that types of non-audit service provide knowledge spillover and increase audit efficiency and effectiveness and thus increase financial reporting quality. We argue that recurring non-audit services undermine auditor independence because of future economic benefits for the auditor (Causholli et al., 2014) and create economic bonding (Beck et al., 1988b). Because the arguments created are ambiguous, we predict an association between recurring (or non-recurring) tax, audit and other related non-audit services and accruals quality.

Our examination will provide a clearer understanding of how non-audit services affect accruals quality over time. Paterson and Valencia (2011) and Abdul Wahab et al. (2014) find 
PAR

32,2

154

that recurring tax-related non-audit services provide some form of knowledge spillover and reduce the likelihood of financial restatements.

3.2.4 Corporate governance variables and accruals quality. Prior research explains that good corporate governance enhances auditor independence. Good governance will demand more audit effort and thus increase auditor independence. The higher earnings qualities, the less tendency for the manager in earnings management practice, the better the independence in auditing. A vast of research link between corporate governance with earnings management (Abed et al., 2012; Baxter and Cotter, 2009; Becker et al., 1998; Flynn, 2008; Gul et al., 2002; Gulzar and Zongjun, 2011; Haber and Braunstein, 2008; Haw et al., 2011; Lin and Hwang, 2010; Machuga and Teitel, 2009; Pergola et al., 2009; Thoopsamut and Jaikengkit, 2009). Therefore, this study predicts an association between corporate governance variables and accruals quality.

\section{Sample selection}

We based our sample on 1,117 firm-year observations from 2009 to 2011. The non-audit services fees and their characteristics were collected manually from annual reports downloaded from the Bursa Malaysia website. We gathered all available corporate governance variables from annual reports manually. We used data extracted from Datastream to calculate our accruals model and other firm characteristics. As is done in other studies, we exclude financial firms from our sample. The first and one-hundredth percentiles of each continuous variable were winsorized to reduce the effect of outliers. Table I tabulates our sample-selection process.

\section{Research method}

\subsection{Regression models}

We opted for the Francis et al. (2005) model of accruals quality, which is a modification of that of Dechow and Dichev (2002)[4]. The Dechow and Dichev model uses firm-wise time-series regressions with total accruals as the dependent variables and the cash flow of previous, current and subsequent years as independent variables. The standard deviation of the residuals for each firm is used as the accrual quality measure. Dechow and Dichev (2002) highlight that the absolute value of the residual is an alternative measure of accrual quality when such a measure is needed for each firm-year. The

Firms listed on tde main board as of 2011

Less

Finance firms

PN17

New Firms on the board in $2010 \quad 28$

New firms on the board in 2011

Firms with no annual report $2012 \quad 37$

Firms with no annual report $2008 \quad 8$

Firms with no annual report 2009, 2010 and 2011

Total Firms

Three years of observations (2009-2011)

Less

Table I.

Firms with no NAS provider

Missing information

Total observations 
reason for accruals quality being chosen in this study lies in Dechow and Dichev's (2002) argument that accrual quality is to be associated with the firm and industry features that are free from earnings manipulation. This construct is recurring and observable and so differs from earnings management, which is considered unobservable.

Based on comments by McNichols (2002), Francis et al. (2005) include two additional independent variables, namely, changes in sales revenue and property, plant and equipment (PPE), on the basis that this helps improve the expectations of current accruals. We use the same model, and because we want the measure on a firm-year basis, we use the absolute value of the residual as the measure of accrual quality. The model is as follows:

$$
T C A=a_{0}+a_{1} O C F_{i, t-1}+a_{2} O C F_{i, t}+a_{3} O C F_{i, t+1}+a_{4} \Delta R E V_{i, t}+a_{5} P P E_{i, t}+v_{i, t}
$$

The variables are as follows:

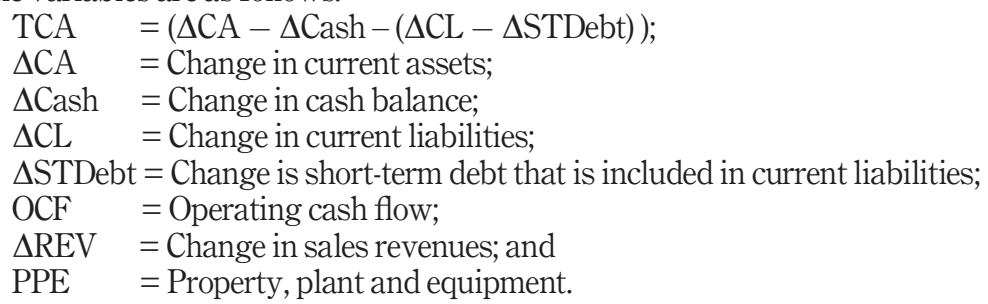

All variables are scaled by average total assets. After computing the residual from (1), we use the absolute value as the dependent variable in the following model, in which to address the first research hypothesis:

$$
\begin{aligned}
\left|v_{i, t}\right|= & \beta_{0}+\beta_{1} \text { NAS }_{i, t}+\beta_{2} \text { ACFIN }_{i, t}+\beta_{3} \text { ACIND }_{i, t}+\beta_{4} \text { ACMEET }_{i, t} \\
& +\beta_{5} \text { ACSIZE }_{i, t}+\beta_{6} \text { DUAL }_{i, t}+\beta_{7} \text { IND }_{i, t}+\beta_{8} \text { BIG4 }_{i, t}+\beta_{9} \text { DEBT }_{i, t} \\
& +\beta_{10} \text { FAMILY }_{i, t}+\beta_{11} \text { BUMI }_{i, t}+\beta_{12} \text { NEQUITY }_{i, t}+\beta_{13} \text { LOSS }_{i, t} \\
& +\beta_{14} \text { POLCON }_{i, t}+\beta_{15} \text { ASSETS }_{i, t}+\beta_{16} \text { INDUSTRIES }_{i, t}+\beta_{17} \text { PERIODS }_{i, t} \\
& +\mu_{i, t}
\end{aligned}
$$

To address the second research hypothesis on types of non-audit services and accruals quality, we have the following model:

$$
\begin{aligned}
\left|v_{i, t}\right|= & \beta_{0}+\beta_{1} \text { TAXNAS }_{i, t}+\beta_{2} \text { ARNAS }_{i, t}+\beta_{3} \text { OTHERS }_{i, t}+\beta_{4} \text { ACFIN }_{i, t} \\
& +\beta_{5} \text { ACIND }_{i, t}+\beta_{6} \text { ACMEET }_{i, t}+\beta_{7} \text { ACSIZE }_{i, t}+\beta_{8} \text { DUAL }_{i, t}+\beta_{9} \text { IND }_{i, t} \\
& +\beta_{10} \text { BIG4 }_{i, t}+\beta_{11} \text { DEBT }_{i, t}+\beta_{12} \text { FAMILY }_{i, t}+\beta_{13} \text { BUMI }_{i, t}+\beta_{14} \text { NEQUITY }_{i, t} \\
& +\beta_{15} \text { LOSS }_{i, t}+\beta_{16} \text { POLCON }_{i, t}+\beta_{17} \text { ASSETS }_{i, t}+\beta_{18} \text { INDUSTRIES }_{i, t} \\
& +\beta_{19} \text { PERIODS }_{i, t}+\mu_{i, t}
\end{aligned}
$$

To address the third research hypothesis on the relationship between the recurrence of non-audit services and accruals quality, we have the following model: 


$$
\begin{aligned}
\left|v_{i, t}\right|= & \beta_{0}+\beta_{1} \text { NAS_RECUR }_{i, t}+\beta_{2} \text { NAS_NRECUR }_{i, t}++\beta_{3} \text { ACFIN }_{i, t} \\
& +\beta_{4} \text { ACIND }_{i, t}+\beta_{5} \text { ACMEET }_{i, t}+\beta_{6} \text { ACSIZE }_{i, t}+\beta_{7} \text { DUAL }_{i, t}+\beta_{8} \text { IND }_{i, t} \\
& +\beta_{9} \text { BIG4 }_{i, t}+\beta_{10} \text { DEBT }_{i, t}+\beta_{11} \text { FAMILY Y }_{i, t}+\beta_{12} \text { BUMI }_{i, t}+\beta_{13} \text { NEQUITY }_{i, t} \\
& +\beta_{14} \text { OOSS }_{i, t}+\beta_{15} \text { POLCON }_{i, t}+\beta_{16} \text { ASSETS }_{i, t}+\beta_{17} \text { INDUSTRIES }_{i, t} \\
& +\beta_{18} \text { PERIODS }_{i, t}+\mu_{i, t}
\end{aligned}
$$

Finally, we have the following model to address the fourth research hypothesis when we test the types of recurrence of non-audit services simultaneously:

$$
\begin{aligned}
& \left|v_{i, t}\right|=\beta_{0}+\beta_{1} \text { TAXNAS_RECUR } R_{i, t}+\beta_{2} \text { TAXNAS_NRECUR } R_{i, t} \\
& +\beta_{3} \text { ARNAS_RECUR } R_{i, t}+\beta_{4} \text { ARNAS_NRECUR }{ }_{i, t}+\beta_{5} \text { OTHERS_RECUR } R_{i, t} \\
& +\beta_{6} \text { OTHERS_NRECUR } R_{i, t}+\beta_{7} \text { ACFIN }_{i, t}+\beta_{8} \text { ACIND }_{i, t}+\beta_{9} \text { ACMEET }_{i, t} \\
& +\beta_{10} A C S I Z E_{i, t}+\beta_{11} D U A L_{i, t}+\beta_{12} I N D_{i, t}+\beta_{13} B I G 4_{i, t}+\beta_{14} D E B T_{i, t} \\
& +\beta_{15} \text { FAMILY }_{i, t}+\beta_{16} \text { BUMI }_{i, t}+\beta_{17} \text { NEQUITY }_{i, t}+\beta_{18} \text { LOSS }_{i, t} \\
& +\beta_{19} \text { POLCON }_{i, t}+\beta_{20} \text { ASSETS }_{i, t}+\beta_{21} \text { INDUSTRIES }_{i, t}+\beta_{22} \text { PERIODS }_{i, t} \\
& +\mu_{i, t}
\end{aligned}
$$

\subsection{Independent test variables}

The primary independent variable in this study is non-audit fees (NAS). As in other studies (Bloomfield and Shackman, 2008; Huang et al., 2007; Kinney et al., 2004; Seetharaman et al., 2011), non-audit fees that are deflated by total fees (NAS) are our measure for NAS. Nonaudit fees are segregated into several types that are deflated by total fees. These are taxrelated NAS (TAXNAS), audit-related NAS (ARNAS) and other NAS (OTHERS). Like Paterson and Valencia (2011), we examine recurring (NAS_RECUR) and non-recurring NAS $\left(N A S \_N R E C U R\right)$, recurring (TAXNAS_RECUR) and non-recurring tax-related NAS (TAXNAS_NRECUR), recurring (ARNAS_RECUR) and non-recurring audit-related NAS (ARNAS_NRECUR) and recurring (OTHERS_RECUR) and non-recurring other NAS (OTHERS_NRECUR). Also, like Paterson and Valencia (2011), we use consecutive periods to determine whether the fees for each type of NAS are recurring or non-recurring[5]. The general rule for the coefficients of the variables mentioned above is positive if it reflects a decrease in accruals quality and thus impairs auditor independence (because an increase in $v_{\mathrm{i}, \mathrm{t}}$ denotes a decrease in accruals quality). Negative coefficients for the abovementioned variables denote an increase in accruals quality (because a decrease in $v_{\mathrm{i}, \mathrm{t}}$ denotes an increase in accruals quality).

\subsection{Corporate governance variables}

Two sets of corporate governance variables exist. The first is board characteristics, and the second is audit committee characteristics. Board characteristics comprise two variables: the proportion of independent directors on the board (IND), and an indicator variable that is equal to 0 if the chief executive officer (CEO) chairs the board of directors (DUAL), and one otherwise. We offer four variables to represent audit committee characteristics: dummy 
variable that is equal to 1 if the audit committee is composed entirely of independent directors $(A C I N D)$; a dummy variable that is equal to 1 if the audit committee is composed of more than two-thirds of financially literate members (ACFIN); the proportion of an audit committee meeting to the audit committee size (ACMEET); and the natural logarithmic transformation of the number of audit committee members (ACSIZE). The premise of this relationship is that a positive relationship exists between corporate governance variables and accruals quality.

\subsection{Institutional variables}

To provide a more holistic view of Malaysia's capital market, we include three variables that are established in the literature. The first is the proportion of Bumiputras directors on the board $(B U M I)$, the second is an indicator variable that is equal to 1 if the firm is a family firm $(F A M I L Y)$ and the third is another indicator variable that describes politically-connected firms $(P O L C O N)$. We predict a negative relationship between $B U M I$ and accruals quality because they are viewed as being less transparent and high in secrecy (Haniffa and Cooke, 2002). We predict a positive and negative relationship with earnings quality for FAMILY and POLCON.

\subsection{Control variables}

We control for firm size, which is the natural logarithmic transformation of total assets (ASSETS); debt to total equity (DEBT); auditor size, which is equal to 1 if the firm is audited by a Big 4 auditor (BIG4); and a dummy variable if the firm recorded a loss in the previous year (LOSS). We also include industry dummies (INDUSTRY) and period dummies (PERIOD) to control for any unobserved effects during the sample period[6]. Please refer to Table II for the operational definitions of the variables.

\subsection{Data description}

Table III tabulates the descriptive statistics used in our study. The average $A Q$ is 0.043 , which ranges from 0.000 to 0.389 . Panel $\mathrm{A}$ in Table III describes the fee variables. The average audit fees (AFEE) are RM 190921.600, with a maximum of RM 3.843m[7]. The average non-audit fees (NAS_RM) are RM 49162.950, with a range between RM 105m and RM 2.412m. TAX_RM, ARNAS_RM and OTHERS_RM average RM9263.320, RM 18324.860 and $\mathrm{RM}$ 21574.770, respectively. The average RECURRING_RM and NON_RECUR_RM non-audit fees are RM 43771.550 and RM 5391.403, respectively. The proportion of total non-audit fees to total fees is 0.179 , with OTHERS comprising the highest proportion of total fees at 0.080 .

Panel B of Table III presents descriptive statistics for corporate governance variables. In the sample firms, 69.2 per cent separates the $C E O$ and Chairperson (DUAL) function, 44.2 per cent of sample firms have at least two-thirds of independent directors (IND) and 88.4 per cent have independent audit committee members. On average, an audit committee meets 4.818 times per year (ACMEET), and audit committees have three members on average (ACSIZE).

Panel $\mathrm{C}$ of Table III tabulates descriptions of the institutional variables. On average, the proportion of Bumiputras directors $(B U M I)$ is 0.315 , with a range from zero to all being Bumiputras. More than half of the sample firms (55.7 per cent) have some form of family connection (FAMILY), and 9.1 per cent are politically connected (POLCON).

Panel D of Table III presents descriptive statistics for our control variables. A value of 60.3 per cent of sample firms is audited by a Big 4 auditor (BIG4). The average debt-to- 
PAR
32,2

158

Table II.

Operational definition of variables

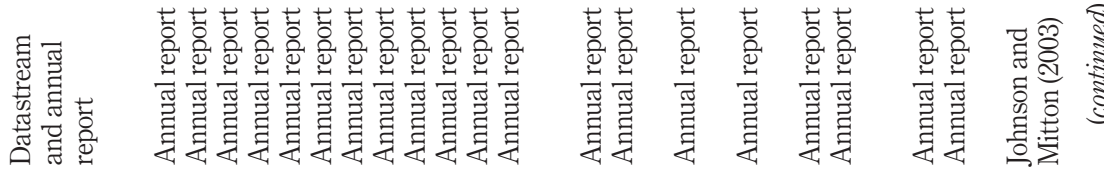

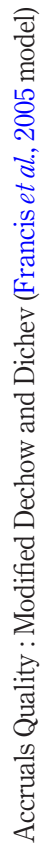

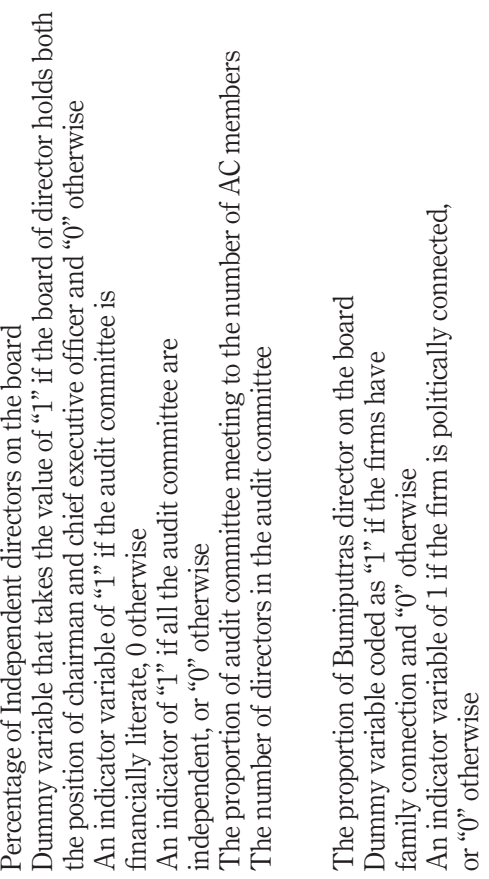

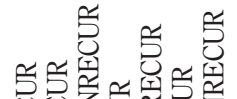

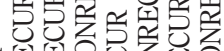

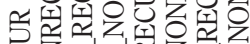

है

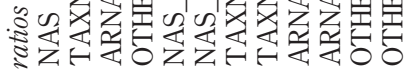

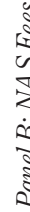

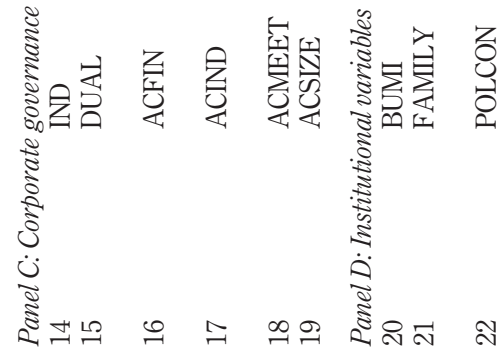




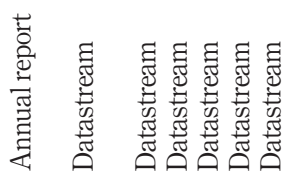

Accruals quality in

Malaysia

159

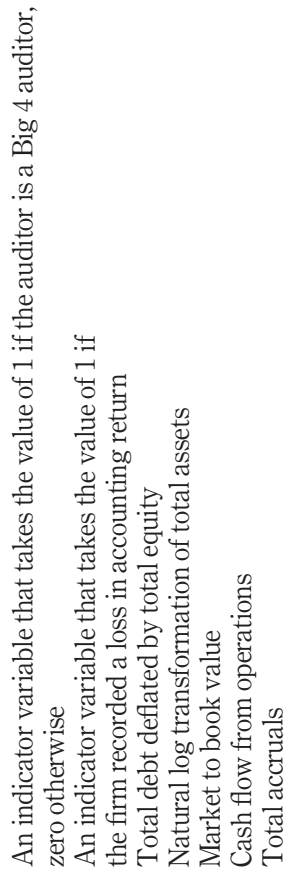

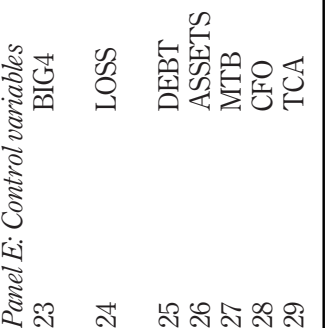

Table II. 


\section{PAR \\ 32,2}

160

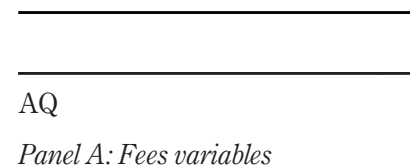

AFEE

TFEE

NAS_RM

TAX_RM

ARNAS_RM

OTHERS_RM

RECURRING_RM

NON_RECUR_RM

TAXRECUR_RM

TAX_NONRECUR_RM

ARNAS_RECUR_RM

ARNAS_NONRECUR_RM

OTHERS_RECUR_RM

OTHERS_NONRECUR_RM

NAS

TAXNAS

ARNAS

OTHERS

NAS_RECUR

NAS_NONRECUR

TAXNAS_RECUR

TAXNAS_NONRECUR

ARNAS_RECUR

ARNAS_NNRECUR

OTHERS_RECUR

OTHERS_NONRECURR

Panel B: Corporate governance

IND

DUAL

ACFIN

ACIND

ACMEET

ACMEET (NUMBER)

ACMEET(LOG)

ACSIZE (NUMBER)

ACSIZE

Panel C: Institutional variables

BUMI

FAMILY

POLCON

$$
\begin{array}{r}
19092 \\
24008
\end{array}
$$

190921.600

$40084.600-159000.000$

49162.950

9263.320

18324.860

21574.770

43771.550

5391.403

8415.984

847.335

15410.360

2914.503

19945.200

1629.565

0.179

0.025

0.074

0.080

0.155

0.024

0.022

0.003

0.061

0.013

0.071

0.009

19000.000

$$
0.000
$$

0.000

0.000

14600.000

0.000

0.000

0.000

0.000

0.000

0.000

0.000

0.140

0.000

0.000

0.000

0.104

0.000

0.000

0.000

0.000

0.000

0.000

0.000

0.442

0.308

0.420

0.884

1.536

4.818

1.551

3.184

1.148

0.430

0.000

0.330

1.000

1.670

5.000

1.609

3.000

1.099

3843000.000

12000.000

271275.500

5667000.000

2412000.000

1082000.000

2412000.000

1093000.000

2412000.000

688000.000

1082000.000

356500.000

2412000.000

688000.000

1093000.000

210000.000

0.888

0.714

0.888

0.818

0.888

0.684

0.714

0.519

0.888

0.684

0.818

0.600

21345.000

105.000

362915.500

$0.000 \quad 58801.280$

$0.000 \quad 87476.180$

$0.000 \quad 67126.460$

$0.000 \quad 116867.200$

$0.000 \quad 29980.260$

$0.000 \quad 57397.810$

$0.000 \quad 13317.550$

$0.000 \quad 84446.220$

$0.000 \quad 24714.900$

$0.000 \quad 66657.160$

$0.000 \quad 11306.960$

$0.001 \quad 0.150$

$0.000 \quad 0.088$

$0.000 \quad 0.124$

$0.000 \quad 0.137$

$0.000 \quad 0.152$

$0.000 \quad 0.082$

$0.000 \quad 0.083$

$0.000 \quad 0.030$

$0.000 \quad 0.115$

$0.000 \quad 0.061$

$0.000 \quad 0.133$

$0.000 \quad 0.050$

Panel D: Control variables

BIG4

LOSS

0.315

0.557

0.250

1.000

0.000

0.860

1.000

1.000

1.000

4.330

13.000

2.565

6.000

1.792

0.170

0.000

0.000

0.500

0.330

1.000

0.000

2.000

0.693

0.126

0.462

0.194

0.152

0.361

1.034

0.210

0.478

0.133

Table III.

DEBT

Descriptive analysis ASSET_RM ('000)

0.091

\subsection{0}

1.000

0.000

0.000

0.288

0.497

0.000

0.498

0.603
0.152
0.223

1.000

0.000

0.170

1.000

0.000

0.489

0.000

0.359

0.690

0.000

0.208

$5,29,000$

$2,88,000$

$35,80,000$

39,887

$6,26,000$

(continued) 


\begin{tabular}{lrrrrr}
\hline & Mean & Median & Maximum & Minimum & \multicolumn{1}{c}{ SD } \\
\hline & & & & & \\
ASSETS & 19.536 & 19.479 & 21.997 & 17.502 & 1.049 \\
MTB & 0.837 & 0.596 & 20.564 & 0.000 & 1.248 \\
CFO & 0.081 & 0.068 & 6.858 & --0.928 & 0.223 \\
TCA & -0.015 & -0.015 & 1.174 & -0.922 & 0.130
\end{tabular}

Notes: Where AQ is the absolute value of the estimation error from the modified Dechow and Dichev model explained by Francis et al. (2005). NAS is the non-audit fees deflated by total fee. Non-audit services are partitioned into TAXNAS, ARNAS and OTHERS. TAXNAS is tax-related non-audit fee deflated by total fees; ARNAS is the audit-related non-audit fees deflated by total fee, and OTHERS is other services non-audit fees deflated by total fees; NAS_RECUR is recurring non-audit services deflated by total fees; NAS_NONRECUR is nonrecurring nonaudit services deflated by total fees; TAXNAS_RECUR is the recurring tax-related non-audit fees deflated by total fees; ARNAS_RECUR is the audit-related non-audit services deflated by total fees; ARNAS _NONRECUR is the audit-related non-audit services deflated by total fees; OTHERS_RECUR is the other services non-audit services deflated by total fees; OTHERS_NONRECUR is the other services non-audit fees deflated by total fees. ACFIN is an indicator of " 1 " if the audit committee is financially literate and also the number of audit committee that become the member of accounting association or " 0 " otherwise. ACIND is an indicator of " 1 " if all the audit committee is independent or "0" otherwise. ACMEET is proportion of audit committee meeting to the numbers of audit committee. ACSIZE is the log number of executive and non-executive director held in the firms. DUAL is the board of director duality, represent by dummy variable takes the value of " 1 " if the board of director holds both position of chairman and CEO and " 0 " otherwise. IND is the board of director independence, percentage of the independent non-executive director in the firm. BIG4 is an indicator variable that takes the value of " 1 " if the auditor is big 4 auditor, "0"otherwise. DEBT is the total debt deflated by total equity. FAMILY is the dummy variable if the firms are owned by more than one family member or "0" otherwise. BUMI is the proportion of Bumiputras board of director in the firms. LOSS is an indicator variable that takes the value of " 1 " if the firm recorded a loss in accounting return, " 0 " other. POLCON is the dummy variables if the firms owned by politically connected firm, or "0" otherwise. ASSETS is the natural log of transformation of total assets. MTB is market-to-book, whereas CFO is cash flow from operations. TCA is total accruals

equity ratio is 0.223 (DEBT). Prior losses have been recorded by 15.2 per cent of the firms studied (LOSS), and the average size of sample firms is RM $529 \mathrm{~m}$.

\section{Results}

\subsection{Univariate analysis}

Table IV tabulates our correlations (Pearson- and Spearman-rank) for continuous variables. Positive and significant correlations exist between NAS, TAXNAS, ARNAS and OTHER and accruals quality $(A Q)$, which lends initial support to the theory that non-audit services create economic bonding and thus undermine independence. As expected, our non-audit services fee variables are positively and significantly correlated with each other. Two of our governance variables, IND and $A C S I Z E$, are positively and significantly correlated with $A Q$, whereas a negative but insignificant correlation exists between $A C M E E T$ and $A Q$.

\subsection{Accruals quality model}

Untabulated results are provided of the dependent variable, where the Dechow and Dichev (2002) model is applied as modified by Francis et al. (2005). As predicted, the coefficient of $\beta_{2}$ is negative, whereas those of $\beta_{1}$ and $\beta_{3}$ are positive. All three have a magnitude of less than 1. The higher coefficient of $C F O_{i, t+1}$, the future figure, over the coefficient of $C F O_{i, t-1}$, indicates that accruals in this sample have a stronger relationship with future cash flows than with previous flows. This result is supported by Srinidhi and Gul (2007). Of the change in sales, the coefficient reveals a positive sign with very significant value, in line with the argument that changes in sales are expected to have higher total current accruals. This 
PAR

32,2

162

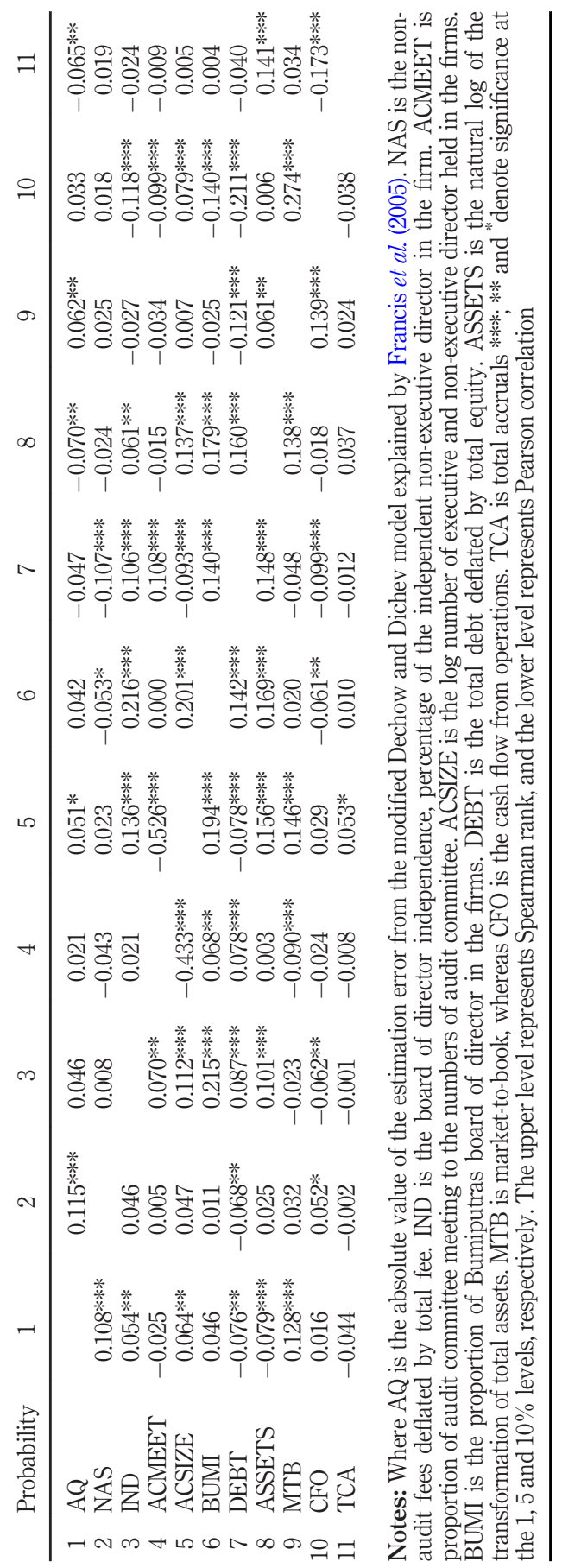

Table IV.

Correlation matrix year 2009-2011 $(N=1,117)$ 
result is in line with the modified Dechow and Dichev (2002) model: firms with a higher gross $P P E$ are likely to be firms with high assets in place and the tendency to have vast amounts of current accruals.

\subsection{Multivariate analysis}

Table $\mathrm{V}$ presents our main set of regressions. Column 1 of Table $\mathrm{V}$ shows the main regression. A positive and significant relationship exists between $N A S$ and $A Q 0.029,(t=$ $3.055, p<0.01$ ), which provides support to the argument that the provision of non-audit services creates economic bonding and thus reduces earnings quality. Our finding is similar to that of Dee et al. (2006), Lim et al. (2013), Frankel et al. (2002), Mande and Son (2015), Reynolds et al. (2004), and Srinidhi and Gul (2007), but is in contrast to that of Antle et al. (2006), Koh et al. (2013), and Larcker and Richardson (2004). In addition, this finding is in contrast to a recent Malaysian study by Abdul Wahab et al. (2014) that examines the relationship between non-audit fees and the likelihood of financial restatements.

Columns 2 to 5 of Table $\mathrm{V}$ present individual regressions based on the type of non-audit fees. We find a positive and significant relationship between TAXNAS, ARNAS and OTHERS and accruals quality. Our findings suggest that types of non-audit services create some economic dependence on the clients but do not generate knowledge spillover. The positive coefficients for OTHERS support the argument by Lai and Krishnan (2009) that the auditor could be reluctant to report material misstatements detected by the accounting or internal system that they designed. Our findings are in contrast to those of Abdul Wahab et al. (2014), Krishnan et al. (2013) and Paterson and Valencia (2011).

We find a positive and significant relationship between $D U A L$ and $A Q(0.004, t=1.279$, $p<0.10$ ), which suggests that having the positions of CEO and Chairperson held by the same person is detrimental to accruals quality. We find a positive and significant relationship between $D E B T$ and $A Q$, but a negative and significant relationship between FAMILY and $A Q$. Columns 1 to 5 of Table $\mathrm{V}$ document a positive and significant relationship between $P O L C O N$ and $A Q$, suggesting that firms with political connection affect accruals quality. This finding is in line with Abdul Wahab et al. (2011). The average variance inflation factor for this regression is 1.160 , which suggests that it does not suffer from multicollinearity. Other variables remain statistically significant, similar to column 1 of Table V.

Table VI tabulates regressions for recurring and non-recurring non-audit fees. Column 3 presents a regression with both variables together. A positive and significant relationship exists for NAS_RECUR $(0.027, t=2.737, p<0.01)$ and NAS_NRECUR $(0.043, t=2.517, p<$ $0.05)$. The nature of both non-audit services creates some form of economic bonding that decreases earnings quality. Our finding is in contrast to the analytical model of Beck et al. (1988a) but is similar to their empirical findings on recurring non-audit services (Beck et al., 1988b). In addition, our finding on recurring non-audit services supports the argument raised by Causholli et al. (2014) that suggests that such an engagement creates economic bonding and could impair auditor independence, but differs from that of Alexander and Hay (2013), as one can view their result as an outcome of knowledge spillover. Interestingly, we find the same positive coefficients for non-recurring non-audit services against accruals quality. This supports the argument raised by Beck et al. (1988a) that non-recurring nonaudit services undermine auditor independence.

We incorporate both types of non-audit services and recurring or non-recurring nonaudit services simultaneously in Table VII. Columns 1 to 6 of Table VII present regressions with recurring and non-recurring types of non-audit fees, whereas column 7 presents the final regression with all variables. We find that TAXNAS_RECUR, ARNAS_RECUR and 


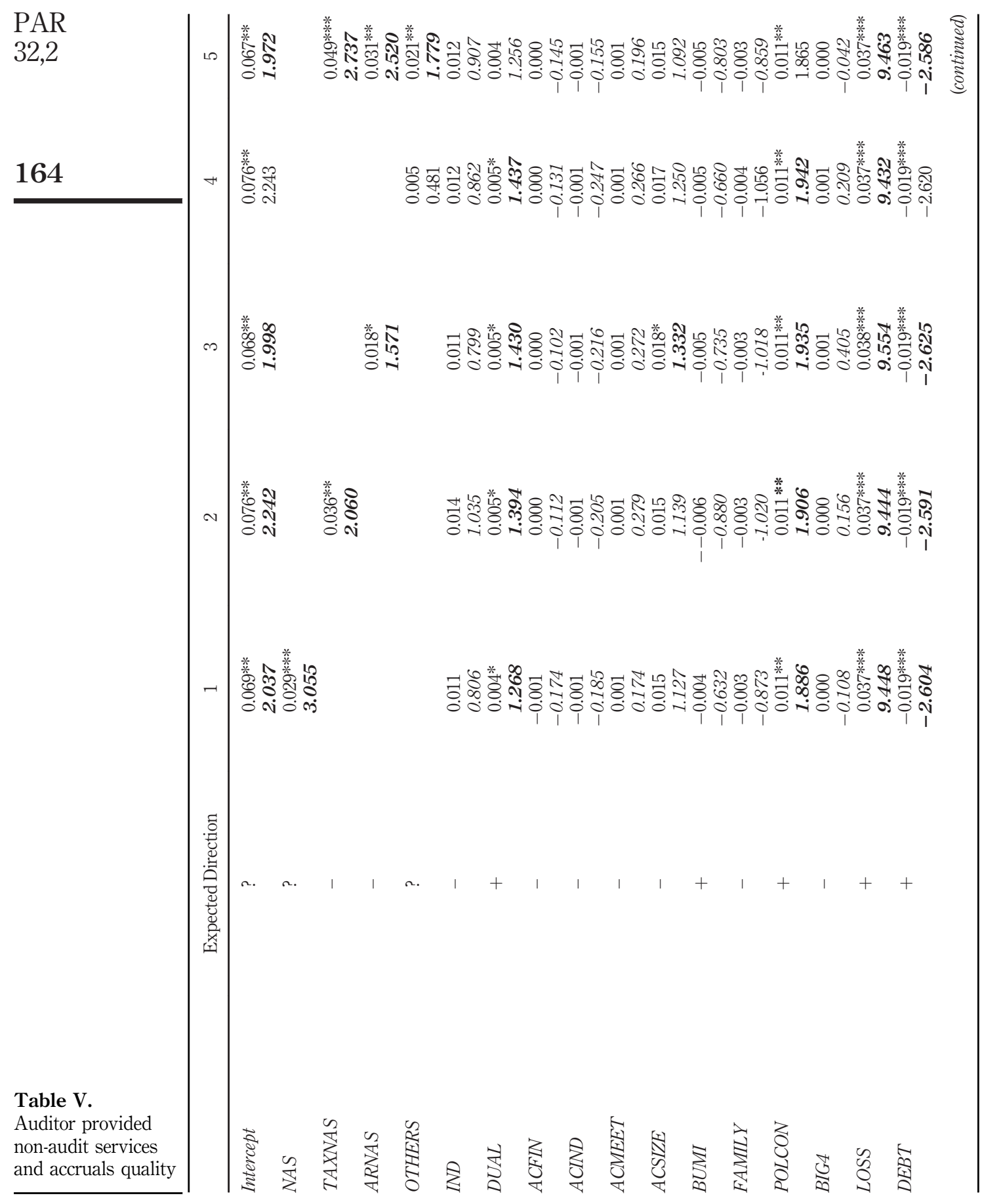




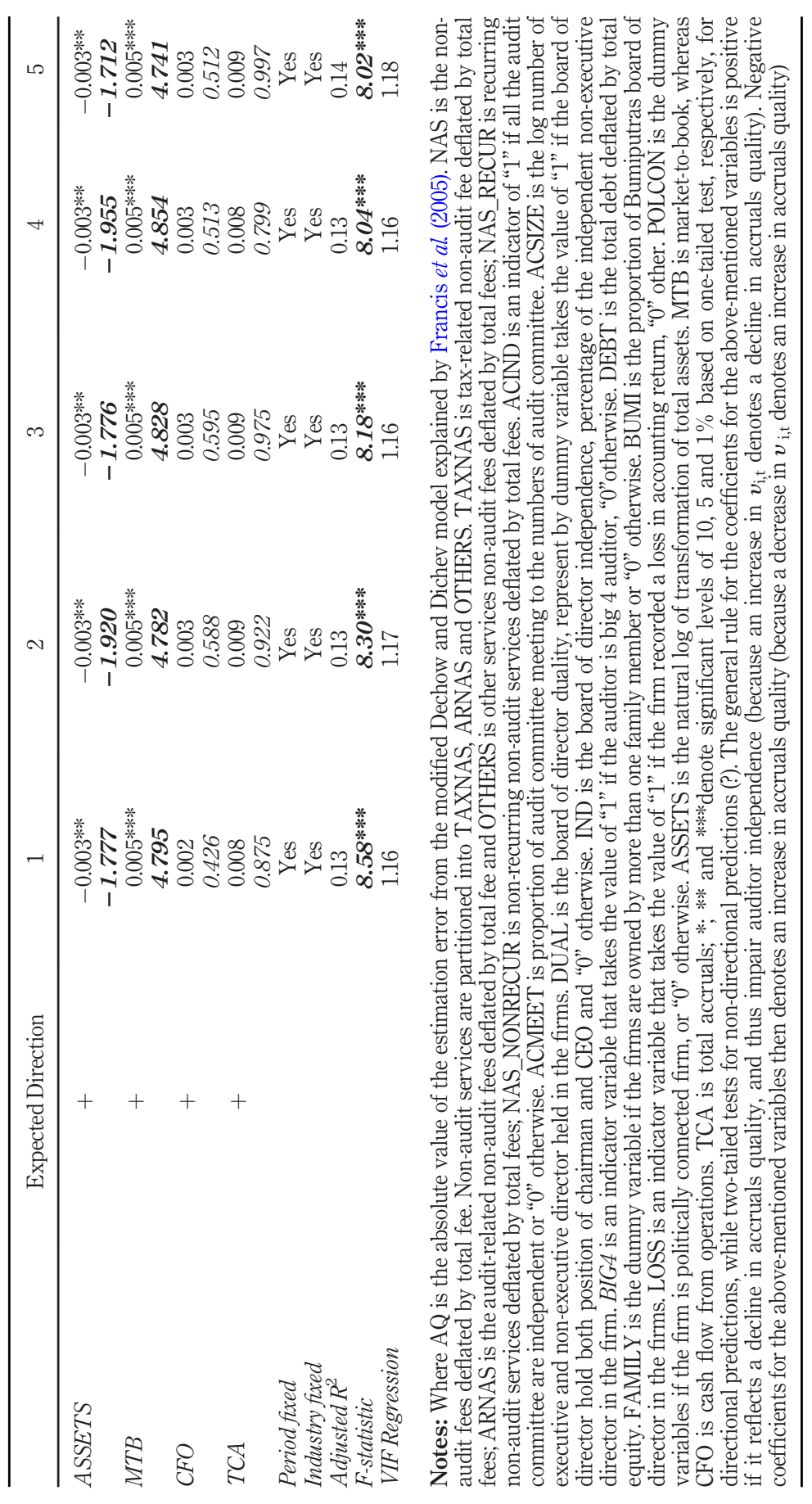

Accruals quality in Malaysia o

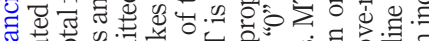

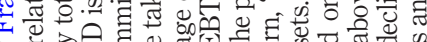

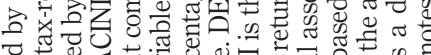

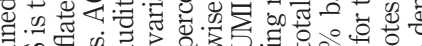

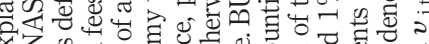

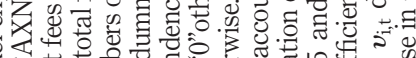

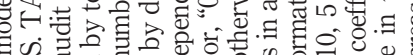

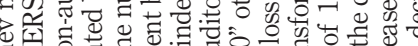

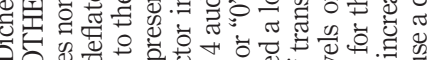

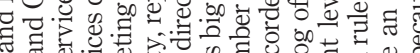

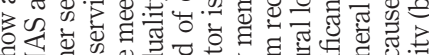

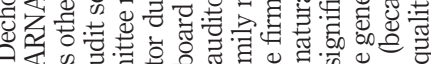

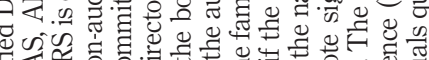

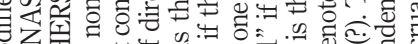

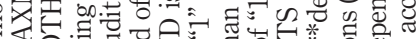

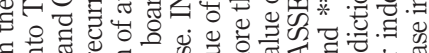

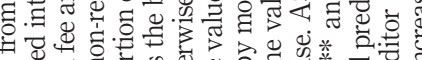

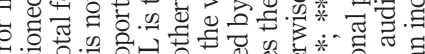
:

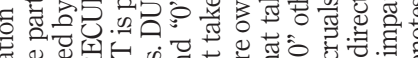
叫

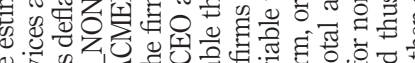
政

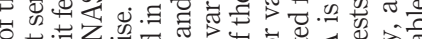
o : 的 o 항

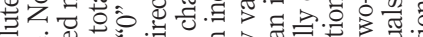

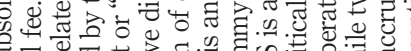

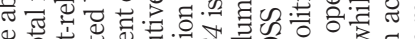

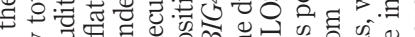

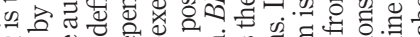

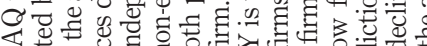

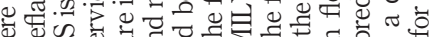
당 is

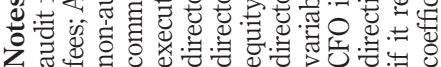




\begin{tabular}{|c|c|c|c|c|}
\hline & Expected Direction & 1 & 2 & 3 \\
\hline \multirow[t]{2}{*}{$\mathrm{C}$} & ? & $0.072^{* * *}$ & $0.071^{* *}$ & $0.066 * *$ \\
\hline & & 2.070 & 2.043 & 1.911 \\
\hline \multirow[t]{2}{*}{ NAS_RECUR } & ? & $0.020 * *$ & & $0.027 * * *$ \\
\hline & & 2.165 & & 2.737 \\
\hline \multirow{2}{*}{ NAS_NONRECUR } & ? & & $0.028^{* *}$ & $0.043 * *$ \\
\hline & & & 1.743 & 2.517 \\
\hline \multirow[t]{2}{*}{ IND } & - & 0.011 & 0.010 & 0.010 \\
\hline & & 0.821 & 0.779 & 0.734 \\
\hline \multirow[t]{2}{*}{ DUAL } & + & $0.004^{*}$ & $0.005^{*}$ & $0.004^{*}$ \\
\hline & & 1.311 & 1.476 & 1.290 \\
\hline \multirow[t]{2}{*}{ ACFIN } & - & 0.002 & 0.003 & 0.003 \\
\hline & & 0.233 & 0.424 & 0.325 \\
\hline \multirow[t]{2}{*}{ ACIND } & - & -0.001 & 0.000 & 0.000 \\
\hline & & -0.096 & -0.033 & 0.007 \\
\hline \multirow[t]{2}{*}{ ACMEET } & - & 0.001 & 0.001 & 0.001 \\
\hline & & 0.238 & 0.312 & 0.213 \\
\hline \multirow[t]{2}{*}{ ACSIZE } & - & 0.016 & 0.019 & 0.016 \\
\hline & & 1.238 & 1.409 & 1.245 \\
\hline \multirow[t]{2}{*}{ BUMI } & + & -0.004 & -0.005 & -0.004 \\
\hline & & -0.549 & -0.712 & -0.611 \\
\hline \multirow[t]{2}{*}{ FAMILY } & - & -0.003 & -0.004 & -0.003 \\
\hline & & -0.834 & -1.073 & -0.861 \\
\hline \multirow[t]{2}{*}{ POLCON } & + & $0.011^{* *}$ & $0.011^{* *}$ & $0.011^{* * *}$ \\
\hline & & 1.948 & 1.988 & 1.936 \\
\hline \multirow[t]{2}{*}{ BIG4 } & - & 0.000 & 0.001 & 0.000 \\
\hline & & -0.014 & 0.321 & -0.065 \\
\hline \multirow[t]{2}{*}{ LOSS } & + & $0.037^{* * *}$ & $0.037^{* * * *}$ & $0.037^{* * * * *}$ \\
\hline & & 9.304 & 9.352 & 9.312 \\
\hline \multirow[t]{2}{*}{ DEBT } & + & $-0.019^{* * * *}$ & -0.019 ** & $-0.019^{* *}$ \\
\hline & & -2.569 & -2.555 & -2.543 \\
\hline \multirow[t]{2}{*}{ ASSETS } & + & $-0.003^{* *}$ & $-0.003^{* *}$ & $-0.003^{* *}$ \\
\hline & & -1.903 & -1.934 & -1.808 \\
\hline \multirow{2}{*}{ MTB } & + & $0.006^{* * *}$ & $0.006^{* * *}$ & $0.006^{* * * *}$ \\
\hline & & 4.643 & 4.761 & 4.708 \\
\hline \multirow[t]{2}{*}{$\mathrm{CFO}$} & + & 0.003 & 0.001 & 0.001 \\
\hline & & 0.501 & 0.212 & 0.184 \\
\hline \multirow[t]{2}{*}{ TCA } & + & 0.001 & 0.001 & 0.001 \\
\hline & & 0.145 & 0.051 & 0.078 \\
\hline & Yes & Yes & Yes \\
\hline \multicolumn{2}{|l|}{$\begin{array}{l}\text { Period Fixed } \\
\text { Industry Fixed }\end{array}$} & Yes & Yes & Yes \\
\hline \multicolumn{2}{|l|}{ Adjusted $R^{2}$} & 0.130 & 0.128 & 0.153 \\
\hline \multicolumn{2}{|l|}{$F$-statistic } & $8.243^{* * * *}$ & $8.124^{* * * *}$ & $8.203^{\text {**** }}$ \\
\hline \multicolumn{2}{|l|}{ VIF Regression } & 1.152 & 1.149 & 1.160 \\
\hline
\end{tabular}

Notes: Where AQ is the absolute value of the estimation error from the modified Dechow and Dichev model explained by Francis et al. (2005). NAS_NONRECUR is nonrecurring non-audit services deflated by total fees; ACFIN is an indicator of " 1 " if the audit committee is financially literate and also the number of audit committee that become the member of accounting association or "0" otherwise. ACIND is an indicator of " 1 " if all the audit committee are independent or " 0 " otherwise. ACMEET is proportion of audit committee meeting to the numbers of audit committee. ACSIZE is the log number of executive and nonexecutive director held in the firms. DUAL is the board of director duality, represent by dummy variable takes the value of " 1 " if the board of director hold both position of chairman and CEO and "0" otherwise. IND is the board of director independence, percentage of the independent non-executive director in the firm. BIG4 is an indicator variable that takes the value of " 1 " if the auditor is big 4 auditor, "0"otherwise. DEBT is the total debt deflated by total equity. FAMILY is the dummy variable if the firms are owned by more than one family member or "0" otherwise. BUMI is the proportion of Bumiputras board of director in the firms. LOSS is an indicator variable that takes the value of " 1 " if the firm recorded a loss in accounting return, " 0 " other. POLCON is the dummy variables if the firm is politically connected firm, or "0" otherwise.

Table VI.

Recurring vs nonrecurring non-audit services and accruals quality ASSETS is the natural log of transformation of total assets. MTB is market-to-book while CFO is cash flow from operations. TCA is total accruals *; **and ***denote significant levels of 10, 5 and $1 \%$ based on onetailed test respectively for directional predictions, while two-tailed tests for non-directional predictions (?). The general rule for the coefficients for the above-mentioned variables is positive if it reflects a decline in accruals quality, and thus impair auditor independence (because an increase in $v_{i, t}$ denotes a decline in accruals quality). Negative coefficients for the above-mentioned variables then denotes an increase in accruals quality (because a decrease in $v_{\mathrm{i}, \mathrm{t}}$ denotes an increase in accruals quality) 


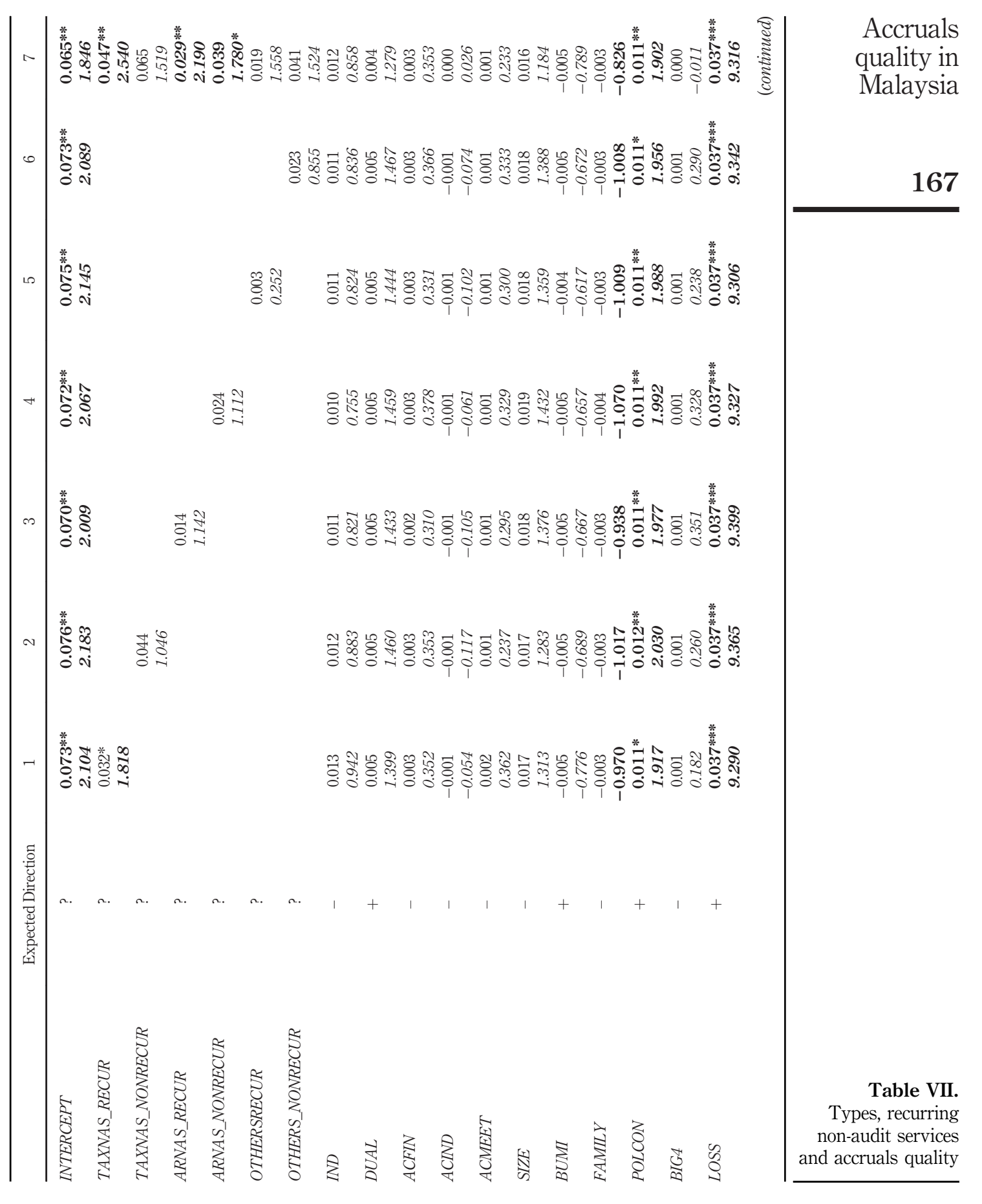


PAR

32,2

168
Table VII.

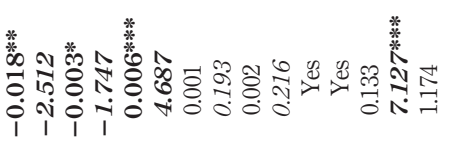

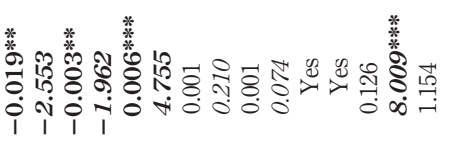

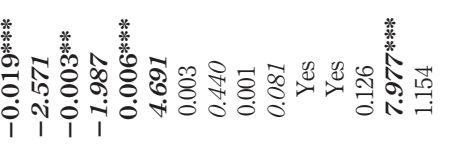
4 华

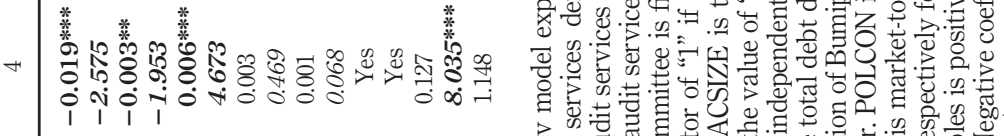

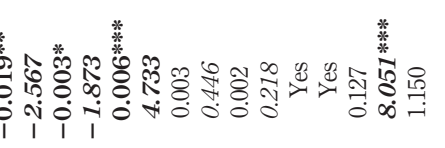

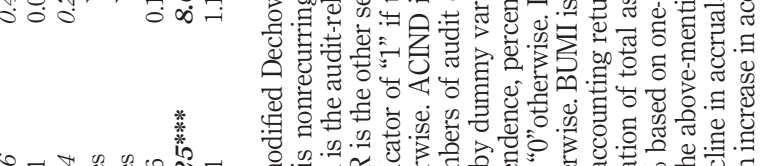

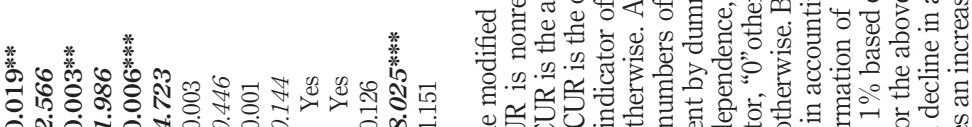

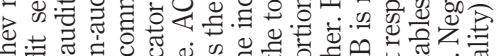

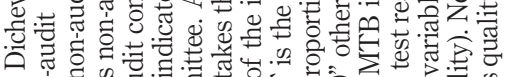
o w

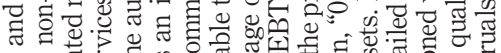

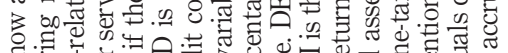

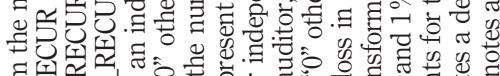

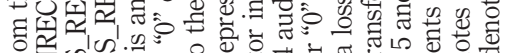
은 to von

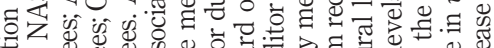

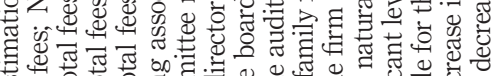

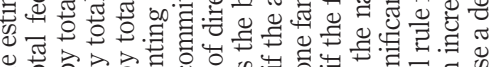

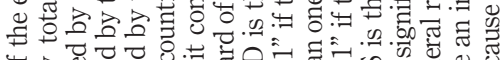

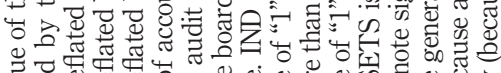

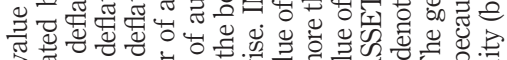

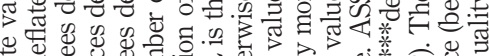

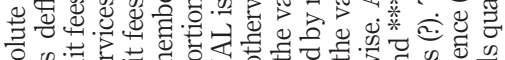

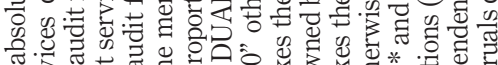

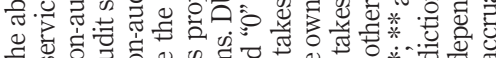

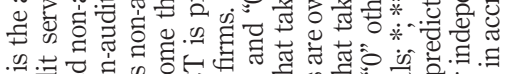

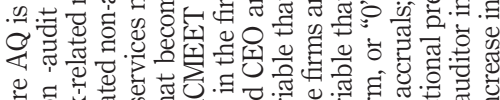

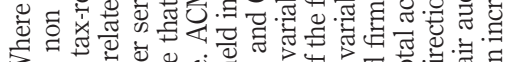

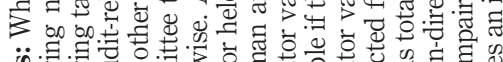

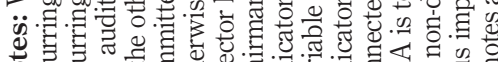

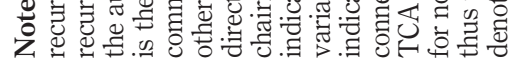


OTHERS_RECUR non-audit services are positively and significantly associated with accruals estimation error, which affects accruals quality negatively. A positive and significant relationship results only between $A R N A S \_N O N R E C U R$ and accruals error and is thus negatively associated with accruals quality. Our results suggest that all recurring and different types of non-audit services could undermine auditor independence.

\subsection{Additional tests}

6.4.1 Auditor size. We extend the analysis by examining the relationship between non-audit fees and accruals quality for Big 4 and non-Big 4 auditors[8]. DeAngelo (1981) argues that accounting firm size is a proxy for auditor independence because no single client is important to a large auditor, and the auditor's greater reputation is at stake if they misreport. By contrast, an accounting firm with only one client may conclude that they have more to gain by complying with the client's demand and that this affects the audit quality (Francis et al., 2004). In addition, larger audit firms could lose more significantly by succumbing to client pressure, and these results in a higher degree of independence (Notbohm et al., 2015). Larger audit firms have better material misstatement abilities, better opportunities to specialize and receive better training in the audit process, which suggests that larger firms provide better audit quality (Notbohm et al., 2015).

Notbohm et al. (2015) provide two reasons why joint provisions of non-audit and audit services by smaller firms provide a higher audit quality. First, differences in audit expertise between small and large audit firms suggest that smaller firms could benefit even more from non-audit services that are provided to the client. Second, in general, larger firms have a greater separation between audit and non-audit personnel than smaller firms, which suggests that knowledge spillover may transfer easier in smaller firms. Notbohm et al. (2015) find that smaller firms that provide tax services have a negative relationship with financial restatements.

The premise of this test relies on the fact that the level of auditor independence depends on the identity of the auditor being Big 4 and non-Big 4. Our non-tabulated results suggest that non-audit fees that are provided by either the Big 4 or non-Big 4 affect accruals quality negatively[9].

We extend the analysis by examining the types of non-audit services. We find that TAXNAS and ARNAS decrease accruals quality when these services are provided by nonBig 4 auditors. This finding supports the argument by DeAngelo (1981) that smaller auditors value non-audit services and have more to gain by complying with their client's demand and suggests a decrease in accruals quality.

6.4.2 Politically connected firms. Given the background of political connections in Malaysia, we perform additional analysis by separating the sample between politically connected firms $(P O L C O N=1)$ and non-politically connected firms $(P O L C O N=0)$. Our untabulated results show that the NAS fees are negatively and significantly associated with accruals quality only for connected firms. The extended analysis finds $A R N A S$ is negatively and significantly associated with connected firms.

6.4.3 Firm size effect. Following Srinidhi and Gul (2007), we perform additional analysis on the size effect. A possible issue with the use of non-audit fee sizes is whether the results are driven mainly by the size of the client firms, and so the fee magnitudes are reflected in this rather than in economic bonding. The earlier result that is tabulated in Table VII proves that a non-audit fee has negative associations with accrual quality; if that fee merely reflected the firm size, their associations with accrual quality would have the same sign.

We find a negative and significant coefficient for the interaction terms NAS * ASSETS $(-0.019, t=-2.032, p<0.05)$, which suggests that the positive relationship between NAS 
PAR

32,2

and accruals quality is less for bigger firms. We observe similar results for TAXNAS and ARNAS non-audit services, but not for OTHERS. Further investigation of recurring and non-recurring non-audit services fees shows that the positive relationship is weaker only for NAS_RECUR and not for NAS_NRECUR. There has been no change in the standalone nonaudit fee variables when we run the interaction terms.

6.4.4 Use of indicators instead of continuous variables. This study repeats the main regression using indicator variables for the magnitude of non-audit fees. In all cases, we represent below-median values of fee variables with an indicator variable value of 0 and above-median values of 1 . This study uses indicator variables to test for the possibility of a threshold level of non-audit fees, above which the benefit to the auditor of retaining the client is higher than any expected cost from litigation and loss of reputation. If this is the case, changes in fees in the regions that lie entirely above or below the threshold level will be inconsequential, and the indicator variables more appropriately confine the effect of fee variables on accrual quality.

We find a positive and significant relationship between $N A S$ (which is equal to 1 if it exists above the median) and accruals quality, which suggests that higher levels of nonaudit service have a negative impact on accruals quality. A similar approach to the types of non-audit services fees provided yields results that are similar to those for tax-related nonaudit services.

6.4.5 Separate analysis for low and high levels of non-audit fees. Following Srinidhi and Gul (2007), this study examines whether the effects of fee variables vary with fee levels. To investigate differences in effect, this study splits the sample into two subsamples for each variable at its median value. For example, the samples are divided into a below-median nonaudit service subsample and an above-median non-audit services subsample, and the effect of the non-audit services is examined within each of the two subsamples. We find a positive and significant relationship between NAS and accruals quality for samples that have nonaudit services above the median value, that is, differences exist between these two subsamples.

\section{Conclusion}

This study contributed to the literature on the role of non-audit services and how they affect accruals quality. Similar to Paterson and Valencia (2011), we add a multi-period dimension while retaining the distinction between fee types. Our results show that auditor-provided non-audit services affect accruals quality negatively, which suggests that these services create economic bonding and undermine independence. Recurring and non-recurring nonaudit services affect accruals quality negatively. All types of recurring non-audit services affect accruals quality adversely. Only non-recurring audit-related services decrease accruals quality. This is a useful addition to the current debate on the role of non-audit services in Malaysia. The findings in this paper are in contrast to Abdul Wahab et al.'s results (2014), provide motivation to push for a regulative approach to the provision of nonaudit services by incumbent auditors and imply that further refinements are warranted as related to the types of service that may be offered by auditors as non-audit services. The findings could suggest a refinement on the MIA by-laws focusing on auditor independence, and these could assist other regulative bodies such as the Securities Commission the stock exchange (Bursa Malaysia) in ensuring better governance on the provision of non-audit services. Further studies need to be conducted in order for Malaysia to follow the USA in restricting the requirements of non-audit services, as the current evidence is rather scarce. 


\section{Notes}

1. Please refer to Principle 5, Uphold Integrity in Financial Reporting in the Revised Code of Corporate Governance under Recommendation 5.2.

2. A prediction of a negative relationship will result in positive coefficients for non-audit fees.

3. Examples of other-related non-audit services are a review of statement of internal control and Financial Reporting Standard conversion study. These services are usually not part of the services permitted by MIA by-laws. However, where a specific service is not addressed in the bylaws, the general provisions that deal with professional independence would apply.

4. Our results remain robust with the Dechow and Dichev (2002) model of accruals quality.

5. Because three years of data are used, we do not consider non-audit fees of a similar type that firms purchased in 2009 and again in 2011, as recurring. The reason for this pattern may be that a different type of NAS was purchased in 2010, or it is possible that the data were unavailable in 2010.

6. For the sake of brevity, we do not report the industries and period dummy coefficients. Results can be obtained from the corresponding author.

7. The data is in Ringgit Malaysia (RM), the currency of Malaysia.

8. For the sake of brevity, tables for these tests are not tabulated. They are available from the corresponding author.

9. A test of differences of mean and median between Big 4 and Non-Big 4 auditors indicates that firms that are audited by Big 4 auditors purchase significantly higher non-audit fees.

\section{References}

Abdul Rahman, R. and Mohamed Ali, F.H. (2006), "Board, audit committee, culture and earnings management: Malaysian evidence", Managerial Auditing Journal, Vol. 21 No. 7, pp. 783-804.

Abdul Wahab, E.A. and Mat Zain, M. (2013), "Audit fees during initial engagement in Malaysia", Managerial Auditing Journal, Vol. 28 No. 8, pp. 735-754.

Abdul Wahab, E.A., Mat Zain, M. and Abdul Rahman, R. (2015), "Political connections: a threat to auditor independence?", Journal of Accounting in Emerging Economies, Vol. 5 No. 2, pp. 222-246.

Abdul Wahab, E.A., Gist, W.E. and Nik Abdul Majid, W.Z. (2014), "Characteristics of non-audit services and financial restatements in Malaysia", Journal of Contemporary Accounting and Economics, Vol. 10 No. 3, pp. 225-247.

Abdul Wahab, E.A., Mat Zain, M. and Abdul Rahman, R. (2013), "Political connections, fees paid to auditor and auditor independence in Malaysia: evidence from going concern audit opinions", International Journal of Accounting, Auditing and Performance Evaluation, Vol. 9 No. 2, pp. 153-183.

Abdul Wahab, E.A., Mat Zain, M. and James, K. (2011), "Political connections, corporate governance and audit fees in Malaysia”, Managerial Auditing Journal, Vol. 26 No. 5, pp. 393-418.

Abed, S., Al-Attar, A. and Suwaidan, M. (2012), "Corporate governance and earnings management: Jordanian evidence”, International Business Research, Vol. 5 No. 1, pp. 216-225.

Agrawal, A. and Chadha, S. (2005), "Corporate governance and accounting scandals", The Journal of Law and Economics, Vol. 48 No. 2, pp. 371-406.

Alexander, D. and Hay, D. (2013), "The effects of recurring and non-recurring non-audit services on auditor independence", Managerial Auditing Journal, Vol. 28 No. 5, pp. 407-425.

Antle, R. (1984), “Auditor independence”, Journal of Accounting Research, Vol. 22 No. 1, pp. 1-20.

Antle, R., Gordon, E., Narayanamoorthy, G. and Zhou, L. (2006), "The joint determination of audit fees, non-audit fees, and abnormal accruals", Review of Quantitative Finance and Accounting, Vol. 27 No. 3, pp. 235-266. 
PAR

32,2

Arruñada, B. (1999), The Economics of Audit Quality: private Incentives and the Regulation, LKluwer Academic Publishers.

Ashbaugh, H., LaFond, R. and Mayhew, B.W. (2003), "Do nonaudit services compromise auditor independence? Further evidence”, The Accounting Review, Vol. 78 No. 3, pp. 611-639.

Baxter, P. and Cotter, J. (2009), "Audit committees and earnings quality", Accounting and Finance, Vol. 49 No. 2, pp. 267-290.

Beck, P.J., Frecka, T.J. and Solomon, I. (1988a), "Model of the market for mas and audit services: knowledge spillover and auditor-auditee bonding", Journal of Accounting Literature, Vol. 7, pp. 50-94.

Beck, P.J., Frecka, T.J. and Solomon, I. (1988b), "An empirical analysis of the relationship between mas involvement and auditor tenure: implications for auditor independence", Journal of Accounting Literature, Vol. 7 No. 1, PP., pp. 65-84.

Benston, G. (1975), “Accountants' integrity and financial reporting”, Financial Executive, pp. 10- 14.

Bloomfield, D. and Shackman, J. (2008), "Non-audit service fees, auditor characteristics and earnings restatements", Managerial Auditing Journal, Vol. 23 No. 2, pp. 125-141.

Causholli, M., Chambers, D.J. and Payne, J.L. (2014), "Future nonaudit service fees and audit quality", Contemporary Accounting Research, Vol. 31 No. 3, pp. 681-712.

Che Ahmad, A., Shafie, R. and Mohamad Yusof, N.Z. (2006), "The provision of non- audit services, audit fees and auditor independence", Asian Academy of Management Journal of Accounting and Finance, Vol. 2 No. 1, pp. 21-40.

Chung, H. and Kallapur, S. (2003), "Client importance, nonaudit services, and abnormal accruals", The Accounting Review, Vol. 78 No. 4, pp. 931-955.

DeBerg, C.L. and Kaplan, S.E. (1991), "An examination of some relationships between non-audit services and auditor change", Accounting Horizons, Vol. 5 No. 1, pp. 17-28.

DeAngelo, L.E. (1981), "Auditor size and audit quality”, Journal of Accounting and Economics, Vol. 3 No. 3, pp. 183-199.

Dechow, P.M. and Dichev, I.D. (2002), "The quality of accruals and earnings: the role of accrual estimation errors", The Accounting Review, Vol. 77 No. S1, pp. 35-59.

Dechow, P., Ge, W. and Schrand, C. (2010), "Understanding earnings quality: a review of the proxies, their determinants and their consequences", Journal of Accounting and Economics, Vol. 50 Nos 2/3, pp. 344-401.

Dee, C.C., Lulseged, A. and Nowlin, T.S. (2006), "Prominent audit clients and the relation between discretionary accruals and non-audit service fees", Advances in Accounting, Vol. 22, pp. 123-148.

Dopuch, N., King, R.R. and Schwartz, R. (2003), "Independence in appearance and in fact: an experimental investigation”, Contemporary Accounting Research, Vol. 20 No. 1, pp. 79-114.

Ezzamel, M., Gwilliam, D.R. and Holland, K.M. (2002), "The relationship between categories of nonaudit services and audit fees: evidence from UK companies", International Journal of Auditing, Vol. 6 No. 1, pp. 13-35.

Flynn, R.S. (2008), "Audit committee compensation and perceived earnings quality: a preliminary investigation”, International Journal of Business Research, Vol. 8 No. 2, pp. 146-152.

Frankel, R.M., Johnson, M.F. and Nelson, K.K. (2002), "The relation between auditors' fees for nonaudit services and earnings management", The Accounting Review, Vol. 77 No. S1, pp. 71-105.

Francis, J., LaFond, R., Olsson, P.M. and Schipper, K. (2004), “Cost of equity and earning attributes", The Accounting Review, Vol. 79 No. 4, pp. 967-1010.

Francis, J., LaFond, R., Olsson, P. and Schipper, K. (2005), "The market pricing of accruals quality", Journal of Accounting and Economics, Vol. 39 No. 2, pp. 295-327.

Francis, J., LaFond, R., Olsson, P. and Schipper, K. (2006), "Earnings quality”, Foundations and Trends in Accounting, Vol. 1 No. 4, pp. 1-84. 
Francis, J.R. (2006), "Are auditors compromised by nonaudit services? Assessing the evidence", Contemporary Accounting Research, Vol. 23 No. 3, pp. 747-760.

Gul, F.A., Lynn, S.G. and Tsui, J.S.L. (2002), "Audit quality, management ownership, and the informativeness of accounting earnings", Journal of Accounting, Auditing and Finance, Vol. 17 No. 1, pp. 25-49.

Gulzar, M.A. and Zongjun, W. (2011), "Corporate governance characteristics and earnings management: empirical evidence from Chinese listed firms", International Journal of Accounting and Financial Reporting), Vol. 1 No. 1, pp. 133-151.

Haber, J. and Braunstein, A. (2008), "Earnings quality ratings and corporate governance: a comparison of two models", Journal of Theoretical Accounting Research, Vol. 3 No. 2, pp. 44-56.

Habib, A. (2012), "Non-audit service fees and financial reporting quality: a Meta-analysis", Abacus, Vol. 48 No. 2, pp. 214-248.

Haniffa, R.M. and Cooke, T.E. (2002), "Culture, corporate governance and disclosure in Malaysian corporations", Abacus, Vol. 38 No. 3, pp. 317-349.

Hasnan, S., Abdul Rahman, R. and Mahenthiran, S. (2013), "Management motive, weak governance, earnings management, and fraudulent financial reporting: Malaysian evidence", Journal of International Accounting Research, Vol. 12 No. 1, pp. 1-27.

Haw, I.H., Simon, S.M. and Li, A.Y. (2011), “Corporate governance and earnings management by classification shifting", Contemporary Accounting Research, Vol. 28 No. 2, pp. 517-553.

Huang, H.-W., Mishra, S. and Raghunandan, K. (2007), "Types of nonaudit fees and financial reporting quality", Auditing: A Journal of Practice and Theory, Vol. 26 No. 1, pp. 133-145.

Johl, S.K., Johl, S.K., Subramaniam, N. and Cooper, B. (2013), "Internal audit function, board quality and financial reporting quality: evidence from Malaysia”, Managerial Auditing Journal, Vol. 28 No. 9 , pp. $780-814$.

Johl, S., Jubb, C.A. and Houghton, K.A. (2007), "Earnings management and the audit opinion: evidence from Malaysia”, Managerial Auditing Journal, Vol. 22 No. 7, pp. 688-715.

Kinney, W.R. Jr., Palmrose, Z.V. and Scholz, S. (2004), "Auditor independence, non-audit services, and restatements: was the US government right?", Journal of Accounting Research, Vol. 42 No. 3, pp. 561-588.

Koh, K., Rajgopal, S. and Srinivasan, S. (2013), "Non-audit services and financial reporting quality: evidence from 1978 to 1980", Review of Accounting Studies, Vol. 18 No. 1, pp. 1-33.

Krishnan, G.V., Visvanathan, G. and Yu, W. (2013), "Do auditor-provided tax services enhance or impair the value relevance of earnings?", The Journal of the American Taxation Association, Vol. 35 No. 1, pp. 1-19.

Larcker, D.F. and Richardson, S.A. (2004), "Fees paid to audit firms, accrual choices, and corporate governance", Journal of Accounting Research, Vol. 42 No. 3, pp. 625-658.

Lai, K.W. and Krishnan, G.V. (2009), “Are non-audit services associated with firm value? Evidence from financial information system-related services", Accounting and Finance, Vol. 49 No. 3, pp. 599-617.

Lai, K.M.Y., Sasmita, A., Gul, F.A., Foo, Y.B. and Hutchinson, M. (2016), "Busy auditors, ethical behavior, and discretionary accruals quality in Malaysia", Journal of Business Ethics, pp. 1-12.

Lim, C., Ding, D. and Charoenwong, C. (2013), "Non-audit fees, institutional monitoring, and audit quality", Review of Quantitative Finance and Accounting, Vol. 41 No. 2, pp. 343-384.

Lim, C.Y. and Tan, H.T. (2008), "Non-audit services fees and audit quality: the impact of auditor specialization", Journal of Accounting Research, Vol. 46 No. 1, pp. 199-246. 
PAR

32,2

Lin, J.W. and Hwang, M.I. (2010), “Audit quality, corporate governance, and earnings management: a Meta-analysis”, International Journal of Auditing, Vol. 14 No. 1, pp. 57-77.

\section{Listing requirements}

McNichols, M.F. (2002), "Discussion of the quality of accruals and earnings: the role of accrual estimation errors", The Accounting Review, Vol. 77 No. S1, p. 61.

Machuga, S. and Teitel, K. (2009), "Board of director characteristics and earnings quality surrounding implementation of a corporate governance code in Mexico", Journal of International Accounting, Auditing and Taxation, Vol. 18 No. 1, pp. 1-13.

Mande, V. and Son, M. (2015), "How do auditor fees affect accruals quality? Additional evidence", International Journal of Auditing, Vol. 19 No. 3, pp. 238-251.

\section{MIA by-Laws}

Mitra, S. (2007), "Nonaudit service fees and auditor independence: empirical evidence from the oil and gas industry", Journal of Accounting, Auditing and Finance, Vol. 22 No. 1, pp. 85-107.

Mohd Saleh, N., Mohd Iskandar, T. and Rahmat, M.M. (2007), "Audit committee characteristics and earnings management: evidence from Malaysia", Asian Review of Accounting, Vol. 15 No. 2, pp. 147-163.

Notbohm, M.A., Paterson, J.S. and Valencia, A. (2015), "The effects of jointly provided tax services and auditor size on restatements", Advances in Taxation, Vol. 22, pp. 109-143.

Parkash, M. and Venable, C.F. (1993), "Auditee incentives for auditor independence: the case of nonaudit services”, The Accounting Review, Vol. 68 No. 1, pp. 113-133.

Paterson, J.S. and Valencia, A. (2011), "The effects of recurring and nonrecurring tax, audit-related, and other nonaudit services on auditor independence", Contemporary Accounting Research, Vol. 28 No. 5, pp. 1510-1536.

Pergola, T.M., Joseph, G.W. and Jenzarli, A. (2009), "Effects of corporate governance and board equity ownership on earnings quality", Academy of Accounting and Financial Studies Journal, Vol. 13 No. 4, pp. 87-114.

Reynolds, J.K., Deis, D.R., Jr,. and Francis, J.R. (2004), "Professional service fees and auditor objectivity", Auditing: A Journal of Practice and Theory, Vol. 23 No. 1, pp. 29-52.

Robinson, D. (2008), "Auditor independence and auditor-provided tax service: evidence from goingconcern audit opinions prior to bankruptcy filings", Auditing: A Journal of Practice and Theory, Vol. 27 No. 2, pp. 31-54.

Schneider, A., Church, B.K. and Ely, K.M. (2006), "Non-audit services and auditor independence: a review of the literature", Journal of Accounting Literature, Vol. 25, pp. 169-211.

Srinidhi, B.N. and Gul, F.A. (2007), "The differential effects of auditors' nonaudit and audit fees on accrual quality", Contemporary Accounting Research, Vol. 24 No. 2, pp. 595-629.

Seetharaman, A., Sun, Y. and Wang, W. (2011), "Tax-related financial statement restatements and auditor-provided tax services", Journal of Accounting, Auditing and Finance, Vol. 26 No. 4, pp. 677-698.

Simunic, D.A. (1984), "Auditing, consulting, and auditor independence", Journal of Accounting Research, Vol. 22 No. 2, pp. 679-702.

Thoopsamut, W. and Jaikengkit, A. (2009), "Audit committee characteristics, audit firm size and quaterly earnings management in Thailand”, Oxford Journal, Vol. 8 No. 1, pp. 3-12.

Walker, A. and Hay, D. (2013), "Non-audit services and knowledge spillover: an investigation of the audit report lag", Meditari Accountancy Research, Vol. 21 No. 1, pp. 32-51. 
Wan Ismail, W.A., Kamarudin, K.A., van Zijl, T. and Dunstan, K. (2013), "Earnings quality and the adoption of IFRS-based accounting standards evidence from an emerging market", Asian Review of Accounting, Vol. 21 No. 1, pp. 53-73.

Yatim, P., Kent, P. and Clarkson, P. (2006), "Governance structures, ethnicity, and audit fees of

Accruals quality in Malaysia Malaysian listed firms", Managerial Auditing Journal, Vol. 21 No. 7, pp. 757-782.

\section{Corresponding author}

Wahab Effiezal Aswadi Abdul can be contacted at: effiezal.abdulwahab@curtin.edu.au

For instructions on how to order reprints of this article, please visit our website: www.emeraldgrouppublishing.com/licensing/reprints.htm Or contact us for further details: permissions@emeraldinsight.com 